【論 文】

UDC : $691: 65.001 .4$

\title{
触覚センサによる建築仕上げ材料の触覚定量化 TACTILE RESPONSE OF BUILDING MATERIALS BY TACTILE SENSOR
}

\author{
岡島達雄*, 吳 健 丹**, 堀越哲美***, 武田雄二****, \\ 水谷章夫*****, 河辺伸二*** \\ Tatsuo OKAJIMA, Jiandan WU, Tetsumi HORIKOSHI, Yuji TAKEDA, \\ Akio MIZUTANI and Shinji KAWABE
}

The object of this paper is to clarify the tactile response of building materials by tactile sensor. We developed the compact tactile sensor that can measure the physical values of warmth, hardness and roughness of building materials. At a temperature of $20^{\circ} \mathrm{C}$, psychological values of warmth, hardness and roughness were obtaind from the physical values of sixty materials by the tactile sensor. The tactile comfort value can be expressed from physical values of warmth, hardness and roughness by the tactile sensor. It was found that physical values of warmth hardness and roughness at $20^{\circ} \mathrm{C}$ can be pridicted from the values measured by the tactile sensor in the region of $10 \sim 30^{\circ} \mathrm{C}$ other than $20^{\circ} \mathrm{C}$. Its applicability was verified.

Keywords : building materials, tactile response, tactile sensor, warmth, hardness, roughness 建築仕上げ材料, 触覚, 触覚センサ, 温冷感, 硬軟感, 粗滑感

1.はじめに

建築空間を構成するにあたって，建築仕上げ材料の選 択は極めて重要であると考えられる。その選択において は,「強度」や，「耐久性」といった物理的性質を満足さ せるとともに，「温かさ」「硬さ」などの感覚的性質に ついても考虑する必要がある。

触感覚を評価するには, 被験者を用いて心理量を求め る直接評定法と，七ンサを用いて得られた物理量を介し て，定量化する間接評定法が有効である。

本研究では, $10^{\circ} \mathrm{C}$ から $30^{\circ} \mathrm{C}$ までの室温における多 種多様な建築仕上げ材料を測定できるような実用的で, コンパクトな触覚センサを開発して, 基本感覚 ${ }^{11}$ の温冷 感, 硬軟感, 粗滑感の物理量を計測し, その値をもとに して, 触覚の心理量を推定することを目的とする。

\section{2. 建築仕上げ材料の触感覚の定量化の既往の研究}

刺激 (stimulus) と，それに対する反応 (response)
の間の関係を数量的にとらえようとするのが精神物理学 である。Weber, Fechnerによれば，感覚量 $R$ と刺激 量 $S$ との間に $R=K \log S$ が成り立つという2)。

建築学の分野における，建築材料と触覚センサとの関 係についての研究は少ないが，その主だったものについ て見てみる。

温冷感について, Hensel は温冷感を構成する刺激と して熱を提唱し，さらに，温・冷の刺激閾を求めた2)。 芝らが温冷感に対応する刺激は温度変化速度であると の前提に立ち，その測定方法について種々の報告をして いる2!。

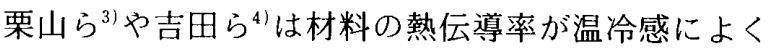
対応すると報告している。

岡島ら ${ }^{5}$ は熱移動量測定器について研究している。 松井ら ${ }^{61}$ は感触温度測定器による測定値から求めた温 度変化速度が温冷感に対応することを報告している。 梶井 ${ }^{71}$ は接触温冷感測定器を用いて, 瞬時の接触温冷
本論文の一部は既に文献 13）において発表した。

* 名古屋工業大学工学部社会開発工学科 教授. 工博

** 名古屋工業大学工学部社会開発工学科 大学院 生・工修

*** 名古屋工業大学工学部社会開発工学科 助教 授・工博

**** 今宮工業工高 教諭・工博

***** 名古屋工業大学工学部社会開発工学科 助手。 工博

****** $\operatorname{INAX}($ 株 $) \cdot$ 工博
Prof., Faculty of Engineering, Nagoya Institute of Technology, Dr. Eng.

Graduate stud. Faculty of Engineering, Nagoya Institute of Technology, M. Eng.

Assoc. Prof,, Faculty of Engineering, Nagoya Institute of Technology, Dr. Eng.

Imamiya Techn. High School, Dr. Eng

Research Assoc., Faculty of Engineering, Nagoya Institute of Technology, Dr. Eng INAX Co. Ltd., Dr. Eng. 
感についで研究している。

硬軟感の定量化について, 岡島ら ${ }^{81}$ は材料のくぼみ剛

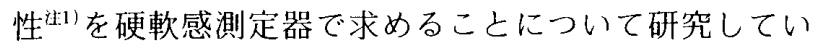
る。

粗滑感の定量化について，岡島ら ${ }^{91}$ は粗滑感と材料表 面の動摩擦係数について報告している。

\section{3. 触覚センサの開発}

測定すべき物理量としては，材料・構法の固有の性質 が評価でき，さらに，要求される感覚の心理量との関係 を定量的によらえるようなものでなければならない。し かし，一般の測定器はごく限られた材質の物理量しか測 定できない。そこで, 多種多様の建築仕上げ材料のほと んどを测定できるような実用的でコンパクトな触覚セン サの開発が要望される。本研究は触覚センサで物理量を 測定した触感覚は温冷感と硬軟感と粗滑感である。

\section{1 触覚センサの構造}

開発したセンサは図一1のシステム図と, 図一2の構 造概略図に示したものである。これは温冷感，硬軟感と 粗滑感それぞれの個別センサをコンパクトに総合したも のである。

\section{2 温冷感センサ}

建築仕上げ材料が常温の下に部材として構成されると き，その材料表面での温冷感覚は建築仕上げ材料の表面 の熱量と, 接触した人間の表面部分の熱量との間に起こ る熱の移動量の多少によって決定されることを，筆者ら は既に述へ，検証している5 。

ここでは,この原理によるが，よりコンパクトにした センサを開発する。すなわち，図一2のように，温冷感 センサは，銅素子の直径は $6 \mathrm{~mm}$ ，高さ $25 \mathrm{~mm}$ である。 その中に熱電対が挿入さている。また銅素子のまわりに は，ヒーターとして働くコンスタンタン線が巻かれてい

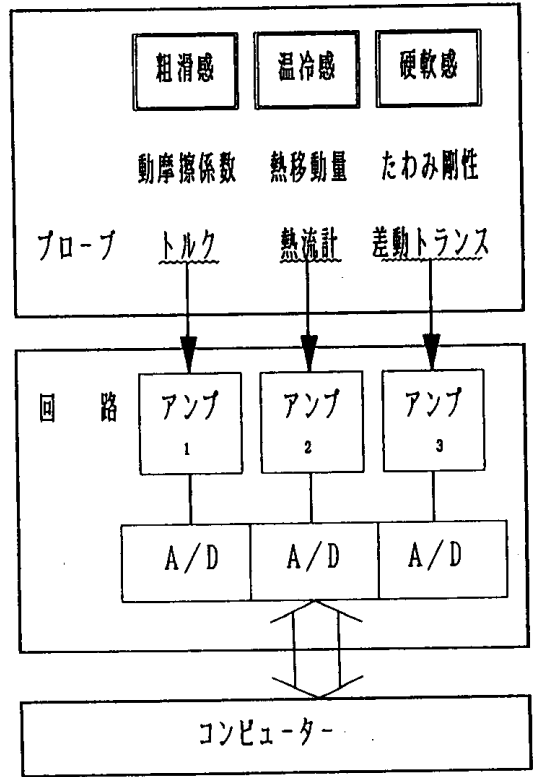

図一1 触覚センサのシステム図

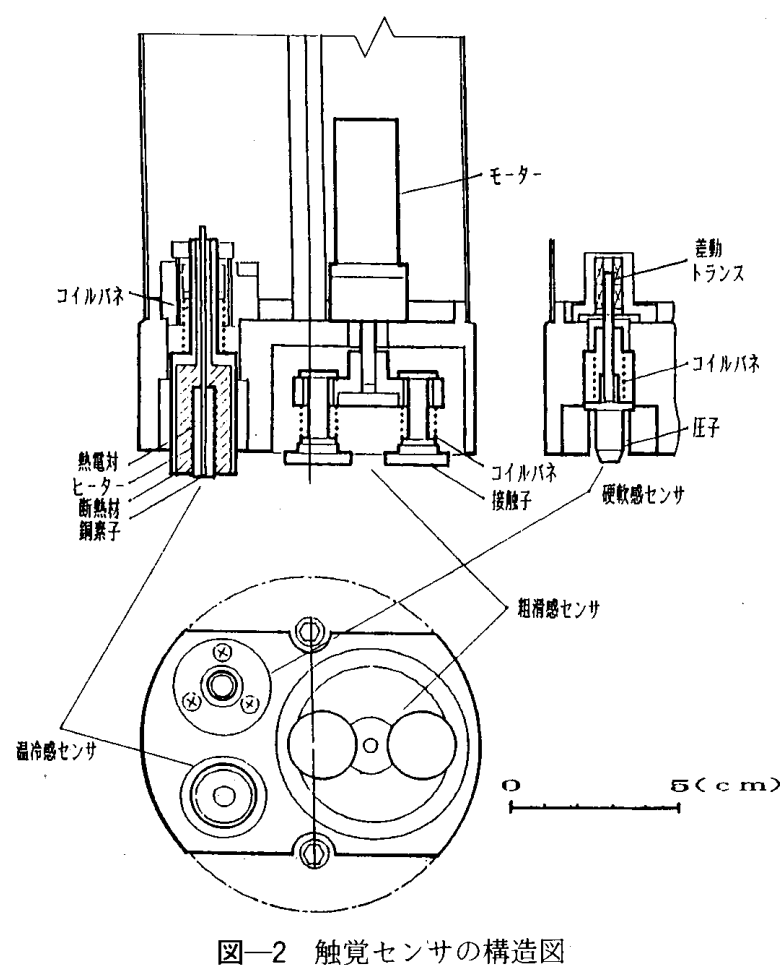

る。さらに，そのまわりには，断熱材としてコルク材が 用いられている。また，コイルバネによって材に加える 荷重を一定にしている。

室温 $20^{\circ} \mathrm{C}$ の時, 電気回路によって銅素子を皮膚の表 面温度亡考えられる $35^{\circ} \mathrm{C}$ に設定する。そして，その銅 素子をこれより低温の試料に接触させる。（ただし，試 料に銅素子が触れた瞬間に $35^{\circ} \mathrm{C}$ を維持していた電気回 路は遮断する) そこで，熱は試料の方へ流れ，銅素子の 温度は低下する。この場合に，銅素子の初期設定温度 $35^{\circ} \mathrm{C}$ から $1^{\circ} \mathrm{C}$ 下がった $34^{\circ} \mathrm{C}$ に至るまでの時間 $\Delta t$ を 測定する。検出部銅素子の保有する熱が試料以外へ移動 しないと仮定すれば，熱移動量は単位面積，単位時間あ たりに移動した熱量と定義できる。熱移動量 $Q$ は次の 式で算定される。

$$
\begin{gathered}
Q=c \rho v \Delta \theta /(\Delta t \cdot f) \cdots \\
Q: \text { 熱移動量 } \\
c: \text { 銅素子の比熱 } \\
\rho: \text { 銅素子の密度 } \\
v: \text { 銅素子の体積 }
\end{gathered}
$$

$\Delta \theta:$ 銅素子の降下温度

$\Delta t:$ 銅素子の温度降下時間

$f:$ 銅素子の接触面積

\section{3 硬軟感センサ}

ある力で材料を押さえつけた場合，“硬”之判断され る材料の表面のくぼみ㳯”は小さく，また“軟”と判断 される材料のくばみは大きいはずである。こうしたこよ から硬軟感覚は，圧感覚に対する平均した刺激，つまり 人間が手で材料を押さえつけたときの材料のくぼみにく さによって決定されることを，筆者らは既に述へ，検証 
している81。

ここでは，この原理によるが，よりコンパクトにした センサを開発する。すなわち，図一2のように，硬軟感 センサは，圧子として直径 $7 \mathrm{~mm}$ のステンレス鋼円柱を 用い，コイルバネが圧力を加えるために組み込まれてい る。また, 差動トランスはコイルバネの変位を読み取る ものである。

室温 $20^{\circ} \mathrm{C}$ の時, 触覚センサの本体からやや突き出し ている死子を，測定しようとする建築仕上げ材料に押し つける。この場合，コイルバネによって材料表面に圧力 が加えられる。ここで, 差動トランスを用いて, 試料に 加えた左力 $\mathrm{P}$ と押し付けたときの圧子の移動量 $L$ を求

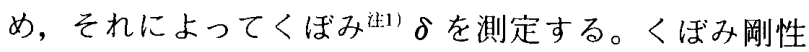
$K$ は次の式で算定される。

$$
\begin{aligned}
& K=P / \delta \\
& K \text { :くぼみ剛性 } \\
& P \text { : 圧子が試料に加えた圧力 } \\
& \delta: く ほ ゙ み ~\left(L_{0}-L\right) \\
& L_{0} \text { ：測定前の圧子の突き出している長さ } \\
& L: \text { 測定時の圧子の移動量 }
\end{aligned}
$$

\section{4 粗滑感センサ}

人間が材料のうえに手をのせて実際に粗さを感じるた めには，指や掌をある程度押しつけた上，押しつける方 向と重直方向に動かしてみることが必要である。そこで, 粗滑感覚はその時の材料表面の凹凸による刺激や手を動 かすときの抵抗の度合い, すなわち，動摩擦係数の多少 によって決定されることを，筆者らは既に述へ，検証し ている ${ }^{9 !}$

ここでは，この原理によるが，よりコンパクトにした センサを開発する。すなわち, 図一2のように, 粗滑感 センサは, 本体から接触子を回転させるために直径 58 $\mathrm{mm}$, 高さ $30 \mathrm{~mm}$ の冈筒形をくり抜き, その中に従動軸 とそれに接続している接触子 2 個が取り付けられてい る。接触子の直径は $18 \mathrm{~mm}$ でフェルトが貼付けられて ある。

室温 $20^{\circ} \mathrm{C}$ の時, 测定する材料に本体を接触させた場 合，接触子がやや突き出しているためコイルバネによっ て一定の圧力が加えられる。そしてモータ一によって接 触子を材料表面で等速回転させる。その時材料表面と接 触子の間に動摩擦力が生じる。その動摩擦力, つまり力 の回転モーメント $T_{r}$ を測定し, 動摩擦係数 $\mu$ を次の式 で求める。

\begin{tabular}{|c|c|c|c|}
\hline & 材 & 香情 & 就枓名 \\
\hline A & 金 用 & $\begin{array}{l}\mathbf{9} \\
2 \\
3 \\
4 \\
5 \\
7 \\
8 \\
9\end{array}$ & 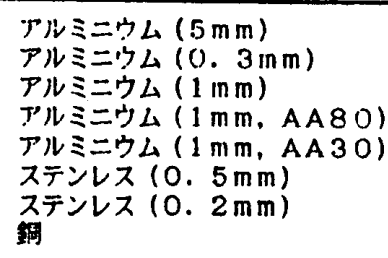 \\
\hline B & 木材 & 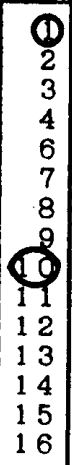 & 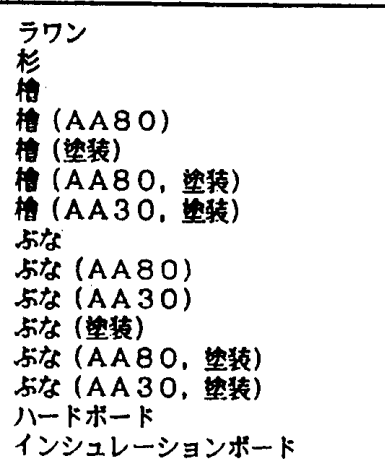 \\
\hline C & セメント & $\begin{array}{l}1 \\
9 \\
3 \\
4 \\
5\end{array}$ & $\begin{array}{l}\text { トリソール } \\
\text { 木毛セメント板 } \\
\text { セxントモルタル板 } \\
\text { ALC } \\
\text { 无㛀セメント板 }\end{array}$ \\
\hline $\mathrm{D}$ & 石 材 & \begin{tabular}{l|}
1 \\
2 \\
3 \\
(4)
\end{tabular} & 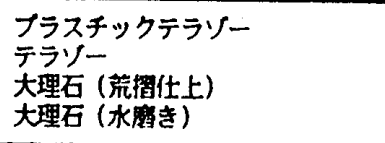 \\
\hline$E$ & $\begin{array}{l}\text { ガラス } \\
\text { 陶磁兴 }\end{array}$ & $\begin{array}{r}1 \\
2 \\
3 \\
4 \\
5 \\
8 \\
6 \\
8 \\
9 \\
10\end{array}$ & 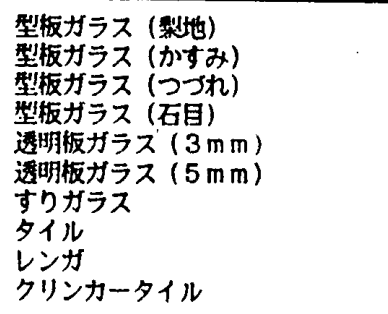 \\
\hline$F$ & 石青 ·石灰 & (1) & 石青板 \\
\hline G & $\begin{array}{l}\text { 离分子 } \\
\text { ブラスチック } \\
\text { 合成樹腘 }\end{array}$ & $\begin{array}{l}1 \\
\mathbf{9} \\
3 \\
5 \\
6 \\
7 \\
8 \\
9\end{array}$ & $\begin{array}{l}\text { アクリル板 } \\
\text { アクリル系吹付材 } \\
\text { リシン(緗目) } \\
\text { プラスチックタイ } \\
\text { ブラスチックタイ (エンボス) } \\
\text { フララスチックタイル(AA80) } \\
\text { ブラスチックタイル (AA30) } \\
\text { エホホキシ板 }\end{array}$ \\
\hline $\mathrm{H}$ & 灌 維 & (3) & $\begin{array}{l}\text { しゅうたん (アクリル) } \\
\text { しゅうたん (パイル峨) }\end{array}$ \\
\hline I & モの他 & $\begin{array}{l}1 \\
2 \\
3 \\
4 \\
5 \\
6 \\
7 \\
8 \\
9\end{array}$ & 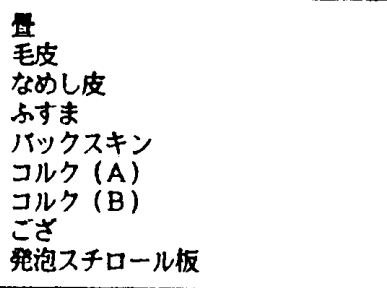 \\
\hline
\end{tabular}

$$
\begin{aligned}
& \mu=T_{r} /(P D) \\
& \mu \text { : 動摩擦係数 } \\
& T_{r} \text { : 力の回転モーメント } \\
& P \text { : 接触子が試料に加えた圧縮力 } \\
& D: 2 つ \text { つ接触子の中心間距離 }
\end{aligned}
$$

\section{4. 物理量の測定}

本研究は心理量の求まった表一1に示すような材質別 9 種, 62 種類の建築仕上げ材料"を対象とする。なお, 本論と文献 1 ) の試料記号の示す試料は同一のものであ る。 


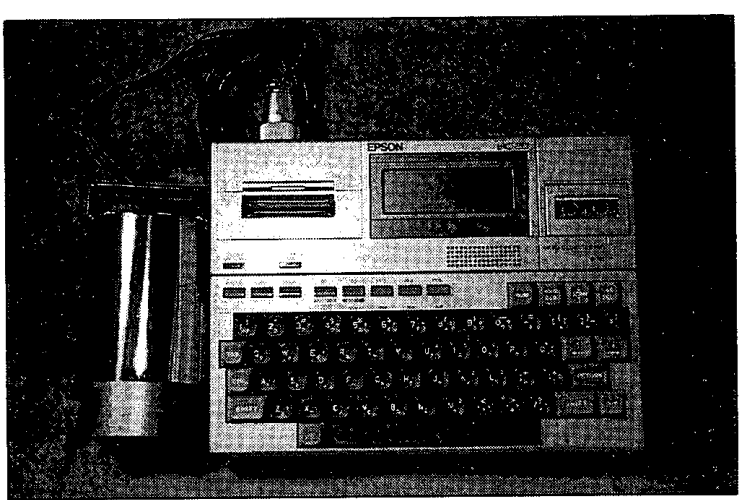

写真一1 测定装置

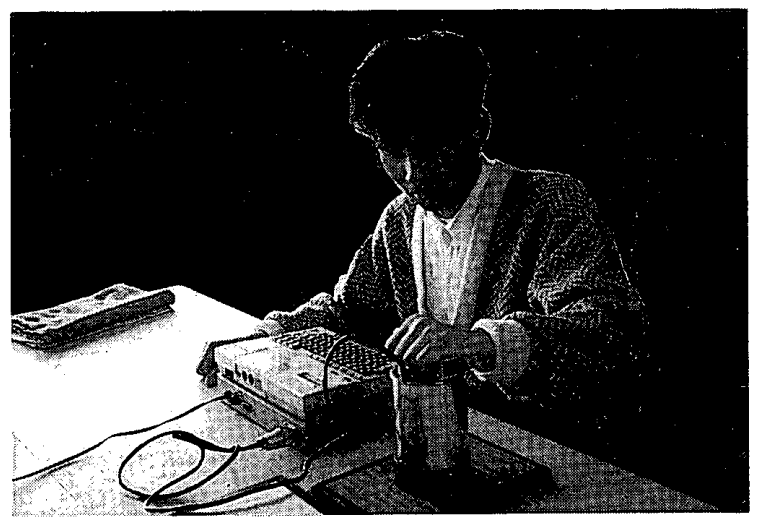

写真一2 測定風景

実験は恒温恒湿室で行った。室内条件は温度を $20 \pm$ $0.5^{\circ} \mathrm{C}$ で一定 (外気温は $20 \pm 2{ }^{\circ} \mathrm{C}$ ), 湿度を $60 \sim 70 \%$ に 設定した。試料は恒温恒湿室内に 1 日間放置し, 設定し た室内温度に達した後, 実験に供した。

各々の試料に対して, 中央, 左上, 右下, 左下, 右上 の順に 5 か所について測定し, 同じ部分の測定は避けた。 測定值は 5 回の測定から中央値を採用し，この測定値を $Q$ (熱移動量)， $P / \delta$ (くぼみ剛性)， $\mu$ (動摩擦係数) に換算したものを実験結果とする。

測定装置および測定の模様を, 写真一 1 , 写真一 2 に 示す。

\section{5. 各感覚の定量化}

\section{1 基本感覚の定量化}

触覚センサにより求めた基本感覚の物理量と心理実験

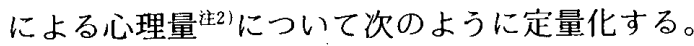

\section{1 .1 温冷感の定量化}

図一 3 には, 表一1に示す全試料について, 室温 $20^{\circ} \mathrm{C}$ での温冷感の心理量とそれに対応する物理量をプロット した。併せて, 回帰分析により求めた両者の関係も示し た。縦軸に前述した心理量を，横軸に物理量としての熱 移動量の対数をとったものである。図中の実線は回帰直 線で, 点線は推定の誤差の標準偏差を示す。各試料とも 片対数座標上で直線関係を示し,両者は高い相関を示す。 求めた回帰直線式を次に示す。

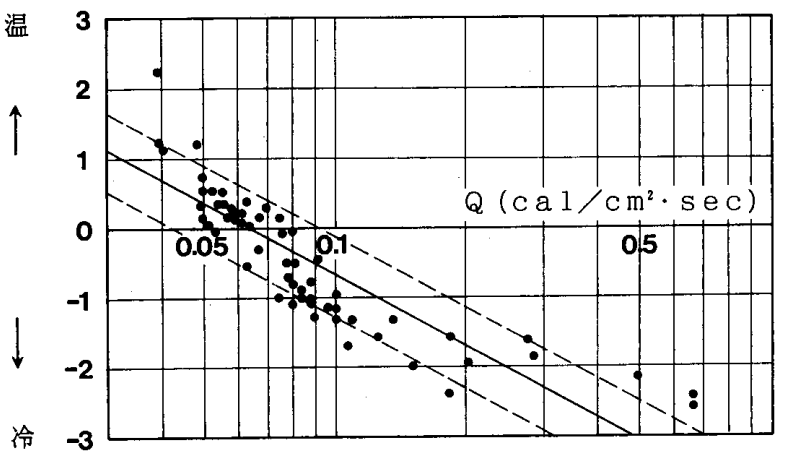

図一3 温冷感心理量亡物理量の相関図

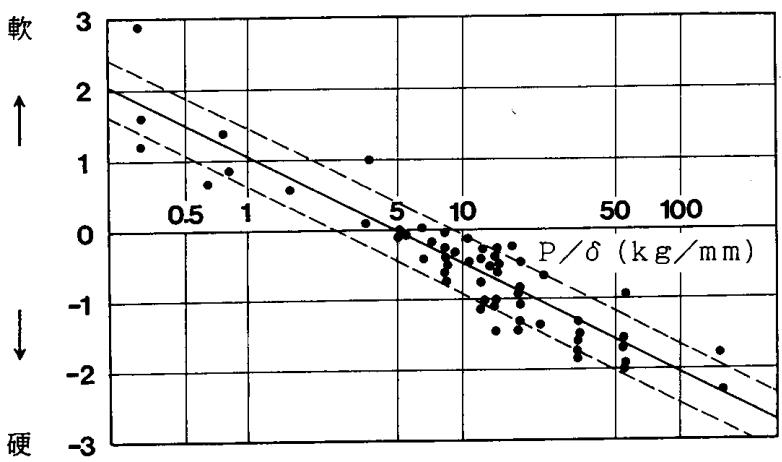

図一4＼cjkstart硬軟感心理量と物理量の相関図

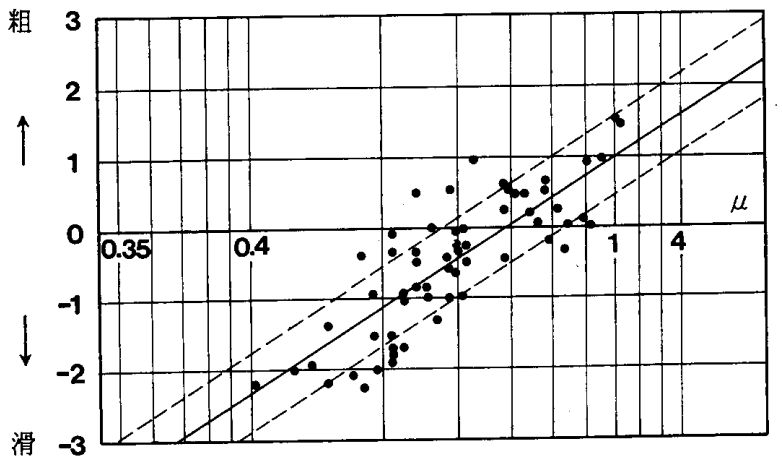

図一5 粗滑感心理量と物理量の相関図

$$
W_{20}=-3.63-2.94 \log (Q)
$$

$W_{20}$ は $20^{\circ} \mathrm{C}$ 温冷感心理量の推定値である。これから, 温冷感の物理量からほぼ正確に心理量が求められるとい える。

5.1 .2 硬軟感の定量化

図一4には，温冷感と同じ方法で，表一1に示す全試 料について, 室温 $20^{\circ} \mathrm{C}$ での硬軟感の心理量とそれに対 応する物理量をプロットした。各試料とも片対数座標上 で直線関係を示し, 高い相関を示す。求めた回帰直線式 を次に示す。

$$
H_{20}=1.0-1.55 \log (K)
$$

$H_{20}$ は $20^{\circ} \mathrm{C}$ 時の硬軟感推定值である。これから, 硬 軟感の物理量からほぼ正確に心理量が求められるといえ る。

\section{1 .3 粗滑感の定量化}

図一 5 にも，温冷感と同じ方法で，表一1に示す全試

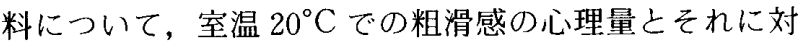


忘する物理量をプロットした。各試料とも片対数座標上 で直線関係を示し，高い相関を示す。求めた回帰直線式 を次に示す。

$$
R_{20}=1.27+8.40 \log (\mu) \cdot
$$

$R_{20}$ は $20^{\circ} \mathrm{C}$ 時の粗滑感推定值である。これから, 粗 滑感物理量からほぼ正確に心理量が求められるといえ る。

\section{2 快・不快感亡粗滑感の定量化}

筆者らの既往の研究 ${ }^{11} に よ り$, 建築仕上げ材料の触覚 的特性の快 - 不快感亡乾湿感の心理量は, 基本感覚の温 冷感, 硬軟感, 粗滑感などの心理量の一次関数としてと らえることができる。

実験結果により，快・不快感は基本感覚である硬軟感 と粗滑感で次のように表される”。

$$
\text { . } A=0.63 H-0.96 R \text {. }
$$

同様に乾湿感は基本感覚の温冷感と粗滑感で次のよう に表される1)。

$$
D=0.60 W+0.40 R
$$

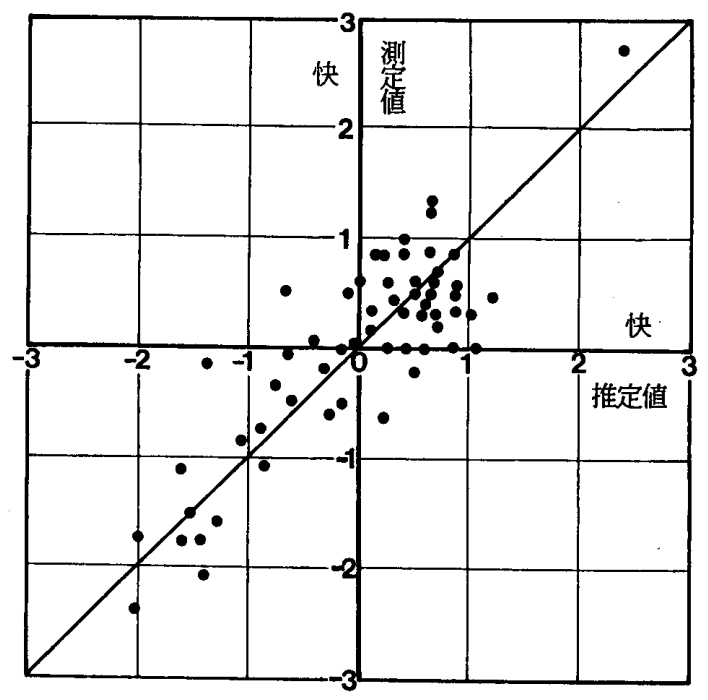

図一6＼cjkstart基本感覚の物理量による推定の相関

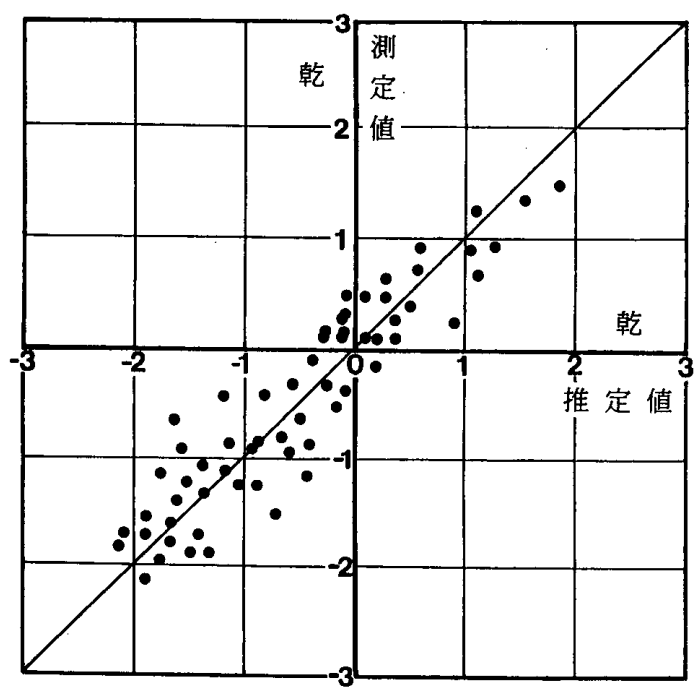

図一7 基本感覚の物理量による推定の相関
$A, H, R, D, W$ は温度 $20^{\circ} \mathrm{C}$ 時の快 - 不快感, 硬軟感, 粗滑感，乾湿感と温冷感の心理量である。

ここでは, 物理量による定量化した基本感覚の心理量 推定値を用いて, 快・不快感などの基本感覚の物理量に よる推定を試みる。

快・不快感，乾湿感の測定值と，式（7)，(8)によ り得られた推定值との対応はそれぞれ図一6，7である。 高い相関を示した。このことから，本研究の結果に関し て, 快・不快感と乾湿感も基本感覚量の物理量で表すこ とができる。

\section{6. 各温度における触覚センサの適合性}

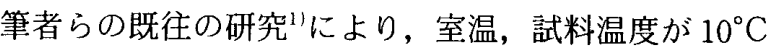
$\sim 30^{\circ} \mathrm{C}$ の範囲内では, 建築仕上げ材料の温冷感, 硬軟感, 粗滑感, 快・不快感および乾湿感は, 常温 $20^{\circ} \mathrm{C}$ の温冷 感，硬軟感および粗滑感の 3 基本感覚で表示される。す なわち, $20^{\circ} \mathrm{C}$ の基本感覚の心理量評定值が分かれば, 温度による触感覚の変化は推定できることが既に検証さ れている。

一方, 本研究では $20^{\circ} \mathrm{C}$ における触覚センサによる物 理量の測定結果より，基本感覚の心理量を推定できるこ とを既に示した。

そこで, 温度が $20^{\circ} \mathrm{C}$ でない時の, 触覚センサの測定 方法について検討する。

6.1 温冷感センサについて

材料表面での温冷感覚は建築仕上げ材料の表面の熱量 と接触した人間の表面部分の熱量との間で起こる熱の移 動量の多少によって決定することができることは既に述 ベた。したがって，本研究の場合は銅素子とこれより低 温の試料との熱交換量である。

参考文献 ${ }^{10)-12)}$ により，銅素子が試料と接触する時, 銅素子と試料を半無限の物体と設定すると，銅素子と試 料の熱交換量は次の式で表される。

$$
q_{m}=\frac{b_{1} b_{2}\left(T_{1}-T_{2}\right)}{\left(b_{1}+b_{2}\right) \sqrt{\pi t}}
$$

ここに,

$$
\begin{aligned}
b= & \sqrt{\lambda c \rho} \\
T_{1} & : \text { 銅素子の設定温度 } \\
T_{2} & : \text { 試料の温度 } \\
b_{1} & : \text { 銅素子の } b \\
b_{2} & : \text { 試料の } b \\
q_{m} & : \text { 熱交換量 } \\
t & : \text { 時間 } \\
\lambda & : \text { 熱伝導率 } \\
c & : \text { 比熱 } \\
\rho & : \text { 密度 }
\end{aligned}
$$

式（9）により, $10^{\circ} \mathrm{C}$ から $30^{\circ} \mathrm{C}$ の範囲で, $\lambda, c$ お よび $\rho$ はぼ一定である'1'から，bもまたほぼ一定よみ 
なせる。すなわち, 同じ試料に対して, 時間 $t$ あたり, 熱交換量 $q_{m}$ は温度差 $\left(T_{1}-T_{2}\right)$ のみ関数として表せる。 6.2 硬軟感七ンサと粗滑感センサについて

筆者らの既往の研究1にによれば, $10^{\circ} \mathrm{C}$ から $30^{\circ} \mathrm{C}$ の範 囲で, 建築仕上げ材料の硬軟感, 粗滑感の心理量には差 がない。また，3.3節ならびに 3.4 節の原理に照らして みると，物理量にも差があるとは言えない。すなわち， $10^{\circ} \mathrm{C} \sim 30^{\circ} \mathrm{C}$ の任意温度でも, 本センサにより, $20^{\circ} \mathrm{C}$ 時 之同じ硬軟感, 粗滑感の測定值が得られると考えられる。 6.3 センサの非温度依存性の検証

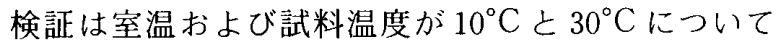
以下のような条件で行う。

実験は 4 節之同じ方法で行った。室内条件は気温をそ れぞれ $10 \pm 0.5^{\circ} \mathrm{C}$ と $30 \pm 0.5^{\circ} \mathrm{C}$, 湿度を $60 \sim 70 \%$ に設 定した。試料は表一1の番号に○印を付けたもの 10 種 類を用いた。

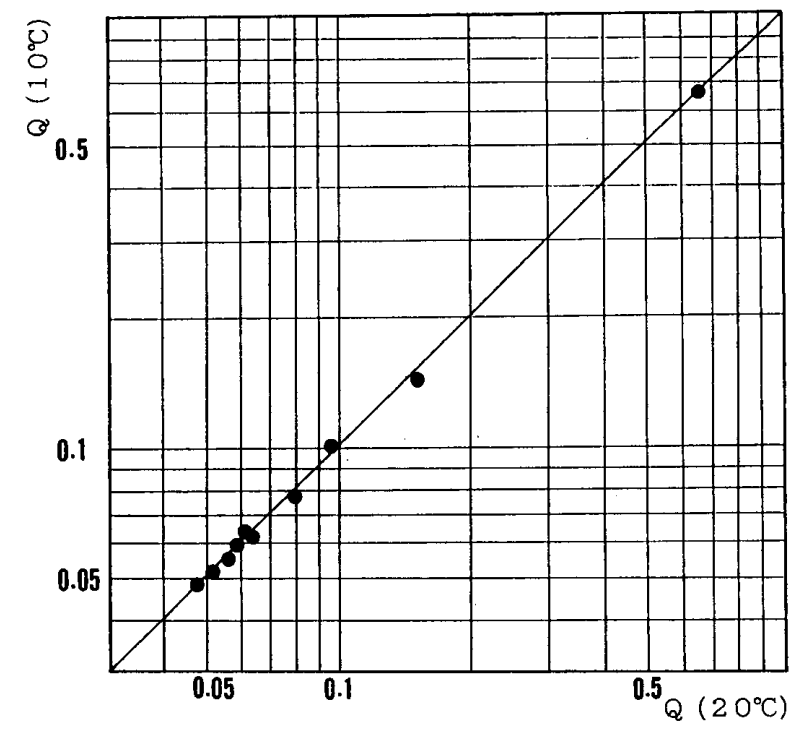

図一8 $10^{\circ} \mathrm{C}$ 温冷感センサの検定図

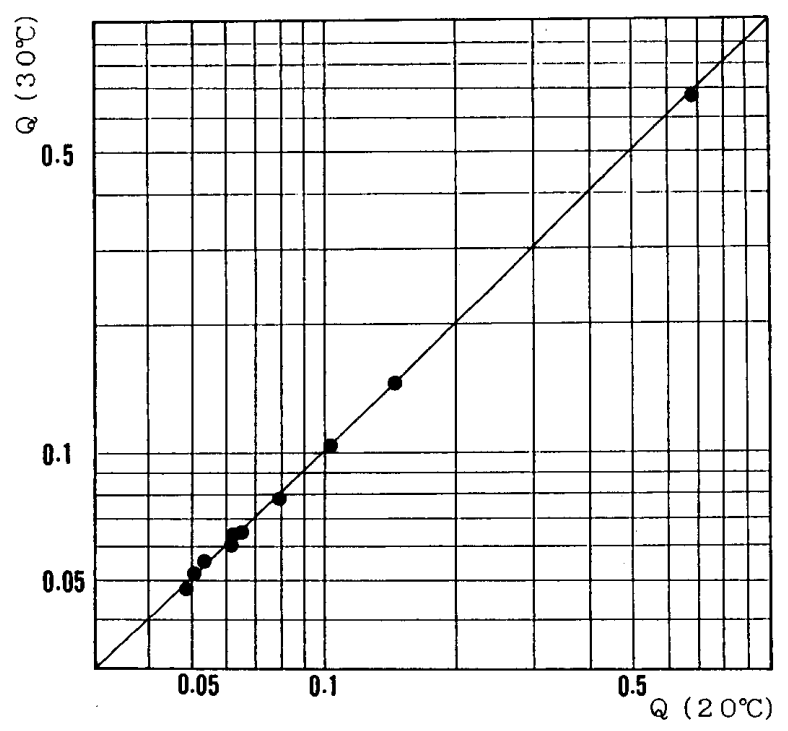

図一9 $30^{\circ} \mathrm{C}$ 温冷感センサの検定図
室温 $10^{\circ} \mathrm{C}$ の時, 温冷感センサの銅素子の温度を $25^{\circ} \mathrm{C}$ とし, 室温 $30^{\circ} \mathrm{C}$ の時, 銅素子を $45^{\circ} \mathrm{C}$ とし, 室温 と素子の温度差はいずれも $15^{\circ} \mathrm{C}$ とした。

室温 $10^{\circ} \mathrm{C}$ と $30^{\circ} \mathrm{C}$ の時のセンサで測定された熱量の 結果を $20^{\circ} \mathrm{C}$ の測定結果と比較して, 図一8, 9 に示す。 図から $10^{\circ} \mathrm{C}$ のも $30^{\circ} \mathrm{C}$ のもう測定結果は $20^{\circ} \mathrm{C}$ の結果 とほぼ一致している。硬軟感と粗滑感も温冷感と同様の 検証を行ったが，温度による差は認められなかった。

以上より， $10^{\circ} \mathrm{C}$ から $30^{\circ} \mathrm{C}$ までの任意の温度域での 基本感覚量はもち万ん, 快・不快感や乾湿感も本センサ から求められる。

\section{7. 結 論}

室温, 試料温度が $10^{\circ} \mathrm{C}$ から $30^{\circ} \mathrm{C}$ の範囲で, 建築仕 上げ材料の触感覚について，次のことが言える。

（1）温冷感・硬軟感・粗滑感の物理量を測定できるコ ンパクトで実用的な触覚センサを開発することができ た。

（2）触覚センサにより温冷感・硬軟感・粗滑感を定量 化して，その值をもとにして心理量を推定することがで きた。

（3）快・不快感の心理量は基本感覚量により推定する ことができる。

（4）乾湿感の心理量は基本感覚量により推定すること ができる。

\section{謝 辞}

本研究を進めるにあたり，大きな刺激を与えていただ いた日本建築学会建築計画委員会建築人間工学小委員会 （主查 岡島達雄）ならびに環境工学委員会 接触感覚 WG (主查 松井 勇 日本大学生産工学部助教授) の 委員各位に厚くお礼申し上げる。卒業研究として本研究 の一部を担っていただいた長谷川利樹氏（現中部電力株 式会社）に厚く謝意を表する。また，センサの製作にご 協力いただいた東洋精機製作所にお礼を申し上げる。

なお，本研究の一部は文部省科学研究費一般 Cによっ ている。記して謝意を表する。

注

1）文献 8$)$ では, “たわみ”あるいは“たわみ剛性”之称し ていた。正確を期するためこれらを“くばみ”あるいは“く ぼみ判性”と称することとした。

2）文献1)では建築仕上げ材の触覚的特性に及ぼす温度の 影響を明らかにすることを目的とし, 数十種の建築材料 を選び出し, 各触賞 (温冷感, 硬軟感, 粗滑感, 快・不 快感, 乾湿感) の特性について, $10,20,30^{\circ} \mathrm{C}$ の気温下 で心理実験を行い, それらを尺度化して, 心理量を求め ている。そして, 気温による各感覚の変化と各感覚間の 相関を調へ，評価した。 


\section{参考文献}

1）岡島達雄ほか 5 名：建築仕上げ材の触覚的特性に及ぼす 温度の影響に関する研究，日本建築学会論文報告集，第 419 号, pp. 1 10, 1991.1

2）和田陽平ほか 2 名：感覚十知覚ハンドブック 誠信書房, pp. 15 17, 778 780, 793 800, 1969.2

3）栗山 寛ほか 2 名：建築仕上げ材料の質感に関する研究 （1）, 日本建築学会大会学術講演梗概集, pp. 191 192, 1968.10

4）吉田正昭ほか 3 名：熱伝導率が異なる物質の表面触，製 品科学研究所報告, No. 60,1976

5）岡島達雄ほか 3 名：建築仕上げ材料の感党的評価に関す 万研究（その1), 日本建築学会論文報告集, 第 245 号, pp. 1 7, 1976.7

6）松井勇ほか1名：仕上材の感触に関する研究(その 2$)$, 日本建築学会論文報告集，第 294 号，pp. 1 12，1980.8

7) 暒井宏修：接触温冷感上材料の放射率, 日本建築学会近 畿支部研究報告集，pp. 205～208，1990
8）岡島達雄ほか 2 名：建築仕上げ材料の感覚的評価に関す る研究 (その 2 ), 日本建築学会論文報告集, 第 246 号, pp. 1 5, 1976.8

9）岡島達雄ほか 2 名：建築仕上げ材料の感覚的評価に関す る研究（その 3$)$ ，日本建築学会論文報告集，第 261 号， pp. $1 \sim 6,1977.11$

10）藤本武助ほ加 1 名伝熱学概論 共立出版, pp. 69 72, 1956: 10

11）川下研介：熱伝導論 オーム社書店，pp. 87～95，5６， 1966. 11

12) H. S. Carslaw and J. C. Jaeger : Conduction of Heat in Solids, OXFORD, pp. 51 91, 1959

13）岡島達雄ほか 2 名：触覚センサによる建築仕上げ材料の 触覚定量化, 日本建築学会大会学術講演梗概集 (E), pp. $665 \sim 666,1990.10$

(1991 年 2 月 10 日原稿受理, 1991 年 5 月 14 日採用決定) 